\title{
De oorlog in de theorie van de rechtvaardige oorlog
}

\author{
Lonneke Peperkamp
}

\begin{abstract}
The war in just war theory

Just war theory has an ancient pedigree. While the substantive norms and application of those norms have always been debated, the debate today is entirely polarized. So polarized, that there seems almost to be a 'war' in just war theory. On one side are representatives of Walzer's conventional position and on the other side so-called revisionists as McMahan, Fabre, Rodin, and Frowe. This paper offers a critical analysis of this dichotomy. While most of the debate so far has been focused on the substantive level, I focus here on the conceptual- and meta-level. My aim is threefold: to assist readers in understanding contemporary contributions to just war theory; to facilitate a truce between both camps by highlighting respective strengths and weaknesses and exposing a certain division of labor; and to suggest improvements for both positions.
\end{abstract}

Keywords: just war theory, revisionism, Walzer, McMahan, Fabre, ethical theory.

\section{Inleiding}

De theorie van de rechtvaardige oorlog kent een rijke geschiedenis. Beginnend bij Plato, Cicero, en Augustinus, ontwikkelde deze theorie zich via Thomas van Aquino, Francisco de Vitoria, Hugo de Groot, en meer recentelijk John Rawls en Michael Walzer tot een substantieel moreel raamwerk. Door de jaren heen heeft de theorie van de rechtvaardige oorlog bewezen een levende en dynamische theorie te zijn, gevormd door de tijdsgeest en afgestemd op de politieke realiteit van de dag. En hoewel er altijd discussie is geweest over de inhoud van de normen en de toepassing daarvan, lijkt het huidige debat over de rechtvaardige oorlog volledig gepolariseerd. Zo gepolariseerd, dat we bijna kunnen spreken van een 'oorlog' in de theorie van de rechtvaardige oorlog. ${ }^{1}$ Aan de ene kant staan voorstanders van de conventionele positie ${ }^{2}$ zoals uiteengezet door Michael Walzer (Walzer 2015), ${ }^{3}$ en aan de ander kant voorstanders van de zogeheten revisionistische positie, waarvan Jeff McMahan, Cécile Fabre, David Rodin, en Helen Frowe belangrijke vertegenwoordigers zijn. ${ }^{4}$

Deze 'oorlog' wordt gekenmerkt door een diepe verdeeldheid en spanning tussen beide posities. Er zijn verhitte discussies op verschillende niveaus: 1) Het conceptuele niveau, ten aanzien van de terminologie en het algemene karakter van de posities; 2) Het substantiële

\footnotetext{
${ }^{1}$ Zie ook Vaha (2013) and Braun (2018).

${ }^{2}$ Ik zal in de volgende sectie duidelijk maken waarom ik deze positie 'conventioneel' noem.

${ }^{3}$ Bijvoorbeeld Henry Shue, David Luban, Brian Orend, Tamar Meissels, A.J. Coates.

${ }^{4}$ Seth Lazar heeft in een aantal recente artikelen dit onderscheid in kaart gebracht: Lazar $(2017 \mathrm{a}, 2017 \mathrm{~b}, 2018)$.
} 
niveau, ten aanzien van de inhoud van de voorgestelde normen (jus ad bellum, jus in bello, en jus post bellum); en 3) Het metaniveau, ten aanzien van de functie en rol van de theorie van de rechtvaardige oorlog. Deze verdeeldheid en spanning manifesteert zich niet alleen in academische literatuur, maar ook op het internet en op conferenties en workshops. Als academicus schrijvend over dit onderwerp begeef ik mij in dit spreekwoordelijke mijnenveld. Om een impressie te geven van de spanning, gebaseerd op mijn persoonlijke ervaringen: de twee stromingen lijken zich voor elkaar af te sluiten, voorstanders van de ene positie bezoeken conferenties van de andere positie niet, en wanneer dat wel gebeurt zijn er uitermate stevige woordenwisselingen. Toen een Amerikaanse collega onlangs op een conferentie aangaf dat hij 'tussen de posities heen zou willen navigeren' werd hem duidelijk gemaakt dat dat onmogelijk is: 'je moet een kant kiezen!'. Recentelijk hebben een aantal theoretici geprobeerd om een brug te slaan door aan te geven dat de posities minder verschillen dan op het eerste gezicht lijkt en/of door een derde weg voor te stellen (Pattison 2016, Braun 2018). Het is de vraag of een dergelijke verzoeningspoging vruchtbaar is.

$\mathrm{Nu}$ weet ik niet of iedereen inderdaad een kant moet kiezen. Bovendien is een dergelijke tweedeling zonder meer simplistisch. ${ }^{5}$ Desalniettemin wordt elke bijdrage aan het debat gedefinieerd in termen van deze tegengestelde posities. Erkenning van deze tweedeling en begrip van de onderliggende verschillen is daarom noodzakelijk voor academici en andere geïnteresseerden. Dit artikel draagt daaraan bij door een kritische analyse van beide posities te bieden. Hoewel alle drie de hierboven genoemde discussiepunten aan bod komen, richt ik mij vooral op de terminologie en de onderliggende theoretische verschillen (het conceptuele- en metaniveau/niveau 1 en 3) omdat die relatief onderbelicht zijn gebleven.

Wat beoog ik te bereiken met deze kritische analyse? Een verzoening is waarschijnlijk een brug te ver: ik zal laten zien dat de posities qua uitgangspunten fundamenteel verschillen en ze bovendien een heel andere taak vervullen. Echter, naast de lezer inzicht te bieden in het huidige debat door de tweedeling bloot te leggen, wil ik met deze analyse bijdragen aan het mogelijk maken van een wapenstilstand tussen beide posities. Een wapenstilstand, waarbij men zich openstelt voor elkaar en een bepaalde taakverdeling erkend wordt, zou een vruchtbaarder debat mogelijk maken, en is daarom te verkiezen boven polarisatie en het zich voor elkaar afsluiten. Bovendien wil ik suggereren dat beide posities in zekere zin beperkt

\footnotetext{
${ }^{5}$ Er zijn vele varianten van de conventionele theorie, en er zijn nog meer varianten van de revisionistische theorie. In dit artikel ga ik niettemin uit van deze vaak gemaakte tweedeling om daar in grote lijnen iets zinvols over te kunnen zeggen.
} 
zijn, en dat zij allebei bepaalde onderdelen van hun theorie zouden mogen versterken of aanvullen.

De opbouw van dit artikel is als volgt. In de volgende sectie bespreek ik het karakter van beide posities en de gebruikte terminologie tegen de achtergrond van de historische ontwikkeling van de theorie van de rechtvaardige oorlog. Deze conceptuele helderheid is de noodzakelijke basis voor de rest van dit artikel. De derde sectie geeft een analyse van de onderliggende theoretische verschillen tussen beide posities. Vervolgens schets ik in de vierde sectie mijn beoordelingskader. In de twee opvolgende secties gebruik ik deze analyse en het beoordelingskader om beide posities te beschouwen en beoordelen. Wat zijn hun sterke en zwakke punten? Door de posities te evalueren aan de hand van vier gangbare algemene criteria voor morele theorieën, en in het licht van de speciale rol van de theorie van de rechtvaardige oorlog, wil ik twee dingen laten zien: A) beide posities hebben een heel andere doelstelling voor ogen, houden zich daardoor bezig met een ander soort van theorievorming, en doen uitspraken op verschillende gebieden, en B) beide posities kunnen desalniettemin en juist daarom - van elkaar leren. ${ }^{6}$ Terwijl conventionalisten kunnen leren van de revisionisten als het gaat om de filosofische coherentie en verklarende kracht van de theorie, erkennen revisionisten in onvoldoende mate de complexe werkelijkheid van oorlog, en kunnen zij leren van de conventionalisten als het gaat om relevantie en toepasbaarheid. Ik zou beide posities dan ook willen aanmoedigen hun theorie te verbeteren. Een volledige en overtuigende theorie van de rechtvaardige oorlog doet recht aan alle vier criteria, en verbindt abstracte normatieve principes met praktisch toepasbare normen. In de conclusie blik ik kort terug en stel ik de vraag of een wapenstilstand mogelijk is.

\section{Typering en terminologie}

Wanneer tegenwoordig gesproken wordt over de 'traditionele' of 'conventionele' of 'orthodoxe' theorie van de rechtvaardige oorlog, dan verwijst men naar Walzers opvatting van die theorie. Zijn hedendaagse klassieker Just and Unjust Wars (1977), is decennia lang toonaangevend geweest. Walzers vertrekpunt is het 'legalistische paradigma'. Zijn conventionele theorie is daarom bovenal een legalistische theorie; het probeert de juridische normen - te vinden in onder andere het VN Handvest en de Haagse en Geneefse Conventies -

\footnotetext{
${ }^{6}$ Dat betekent dat ik niet probeer aan te tonen dat beide posities dichter bij elkaar liggen dan gedacht, of een derde weg wil voorstellen, zoals Pattison en Braun. Mijn bedoeling is om de tweedeling te bezien door de bril van deze twee verschillende gebieden van ethische theorievorming, om daarmee een openstelling en wapenstilstand te faciliteren.
} 
te rechtvaardigen door er het morele fundament voor te leggen. Maar de 'oorlogsconventie' is breder; het bestaat uit normen, gewoonten, professionele richtlijnen, juridische voorschriften, religieuze/filosofische principes en wederkerige afspraken die onze oordelen over militaire actie vormen (Walzer 2015: 44). Het is, met andere woorden, het geheel van normen en waarden waar overeenstemming over bestaat en waarop de internationale morele en juridische orde gestoeld is (Ceulemans 2010: 37). Dat betekent onder andere dat staten als belangrijkste actoren worden gezien. De historische theorie van de rechtvaardige oorlog wordt erkent en gebruikt, maar functioneert slechts als één van de bronnen (Walzer 2006: 25). Walzers theorie heeft tot doel 'ethische categorieën' te bieden aan de hand waarvan men kan discussiëren over verschillende oorlogssituaties (Walzer 2006: 23). Hij creëert een normatieve gemeenschappelijk taal die concrete oordelen en rechtvaardigingen in de politieke werkelijkheid mogelijk maakt (Walzer 2006: 28). Walzer ontwikkelde zijn theorie aldus in lijn met het internationaal recht en als een praktische morele theorie, een theorie die algemeen aanvaardbaar is en specifieke richtlijnen geeft ten aanzien van militair gedrag gedurende de extreme omstandigheden van oorlog.

Op het substantiële niveau leidt deze aanpak tot bepaalde meer specifieke normen verdeeld over de drie welbekende onderdelen van de theorie van de rechtvaardige oorlog: het jus ad bellum (het recht van oorlog) dat criteria geeft om te bepalen wanneer het gerechtvaardigd is een oorlog beginnen; het jus in bello (het recht in oorlog) dat criteria geeft om te bepalen hoe combattanten (veelal soldaten) zich dienen te gedragen; en het jus post bellum (het recht na oorlog) dat criteria geeft om te bepalen op welke manier een rechtvaardige vrede gerealiseerd kan worden. Walzers boek berust op een sterke presumptie tegen oorlog, terwijl hij erkent dat oorlog soms gerechtvaardigd kan worden als een manier om een groter kwaad te voorkomen of herstellen. Het jus ad bellum is restrictief en in overeenstemming met het juridische verbod op het gebruik van geweld: alleen een zelfverdediging tegen militaire agressie is een rechtvaardige reden voor oorlog. In zeer zeldzame gevallen kan een humanitaire interventie eveneens worden gerechtvaardigd, wanneer dat nodig is om gewelddadige handelingen te stoppen die het morele geweten van de mensheid choqueren (Walzer 2006: 102). Het jus in bello gaat uit van de morele gelijkheid van combattanten. Dat betekent dat combattanten, of ze nu vechten voor de agressor of de rechtvaardige partij, legitieme doelen zijn en gedood mogen worden. In oorlog zijn zij elkaars gelijken; ze hebben dezelfde rechten en plichten. Ten aanzien van het jus post bellum is Walzer voorzichtig. De overwinnaar mag maatregelen nemen om toekomstige agressie te voorkomen, reparaties claimen, en misdadigers moeten worden bestraft. Echter, politieke 
reconstructie is slechts bij uitzondering toegestaan, namelijk wanneer het gaat om een inherent agressief en moorddadig regime, en hoeft niet te resulteren in een democratie (Walzer 2012).

Het revisionisme is een verzamelnaam voor theoretici behorend tot een recente kritische stroming binnen de theorie van de rechtvaardige oorlog. Verschillende invloedrijke filosofen stellen dat de conventionele theorie van de rechtvaardige oorlog filosofisch incoherent is (Rodin 2002: 189; McMahan 2009: 1). Deze filosofen worden vaak revisionisten genoemd, omdat ze gemeen hebben dat ze de normen van de conventionele theorie (en soms ook de juridische normen) willen herzien, ofwel reviseren. Het revisionisme is echter geen eenduidige theoretische positie: er zijn vele verschillende revisionisten. Niet alle revisionisten delen dezelfde theoretische uitgangspunten, verschillende herzieningen van substantiële normen worden voorgesteld, en zoals ik in de inleiding heb aangegeven zijn er ook theoretici die tussen de hier beschreven tweedeling heen willen navigeren door aspecten van beide posities te integreren. ${ }^{7}$ Echter, een kritische houding ten aanzien van het bestaande morele en juridische kader is de gemene deler onder revisionisten. Bovendien zijn zij over het algemeen gelijkgestemd voor wat betreft de theoretische uitgangspunten waarop hun theorie gestoeld wordt (zie de volgende sectie). Het vertrekpunt van deze theoretici is niet het legalistische paradigma, de realiteit van oorlogvoering of de historische theorie van de rechtvaardige oorlog, maar de theorie van Walzer waarop de precieze en nauwgezette denkwijze van de analytische filosofie wordt losgelaten. Op basis van een abstract proces van conceptuele analyse en morele redenering, en met gebruikmaking van hypothetische of fictieve voorbeelden, worden normen geformuleerd die vervolgens worden toegepast op de omstandigheden van oorlog. ${ }^{8}$ Bovendien zijn voor revisionisten niet staten, maar individuen het centrale oriëntatiepunt en de basis voor het ontwikkelen van de theorie.

Verschillende revisionisten pleiten voor diverse substantiële herzieningen. Ten aanzien van het jus ad bellum zijn revisionisten vaak restrictiever als het gaat om zelfverdediging van een politieke gemeenschap tegen agressie. Revisionisten wijzen een ongekwalificeerd recht op zelfverdediging tegen agressie af. Ze zijn vaak echter toleranter als het gaat om humanitaire interventies die ten doel hebben grootschalige mensenrechtenschendingen te stoppen of voorkomen, en soms wordt zelfs een redistributieve oorlog gerechtvaardigd (bv. Fabre 2012 en Lippert-Rasmussen 2013, 2017). Het grootste deel van de revisionistische

\footnotetext{
${ }^{7}$ Zij zullen wellicht deze labeling niet op zichzelf van toepassing achten, zoals de Amerikaanse college genoemd in de inleiding, of variaties hierop suggereren. Pattison, bijvoorbeeld, noemt zichzelf een soft revisionist.

${ }^{8}$ Coates (2016: 9) en Frowe (2011: 1).
} 
kritiek is gericht op het jus in bello. Deze kritiek ondermijnt de morele gelijkheid van combattanten. In oorlog, net zoals in een individuele situatie van aanval en zelfverdediging, hebben onrechtvaardige combattanten helemaal geen rechten. Aangezien onrechtvaardige combattanten schuldig zijn aan agressie, mogen alleen zij onderworpen worden aan een tegenaanval (slechts zij zijn liable to attack). Rechtvaardige combattanten hebben niets gedaan om hun recht op leven te verliezen, en zijn aldus geen legitieme doelen. Binnen de revisionistische stroming is er nog relatief weinig aandacht besteed aan het jus post bellum. Niettemin wordt ook hier een herziening van Walzers voorzichtige voorstel bepleit (zie bijvoorbeeld Fabre 2016).

Er is stevig gediscussieerd over de terminologie die wordt gebruikt om beide 'kampen' te duiden. Toen McMahan begon met het bekritiseren van wat hij de 'orthodoxe' positie noemde (McMahan 1994) - de basis voor de morele gelijkheid van combattanten - was het niet duidelijk waartegen hij zich precies afzette. ${ }^{9}$ Hoewel Walzer inderdaad pleit voor een dergelijke gelijkheid, reflecteert dat geen 'orthodoxe' of 'traditionele' positie wanneer we kijken naar de geschiedenis van de theorie van de rechtvaardige oorlog. ${ }^{10}$ Augustinus, Aquino, Vitoria, en Grotius bijvoorbeeld, onderschrijven geen van allen de morele gelijkheid van combattanten. Bovendien hadden ook hun theorieën het individu als fundamentele bouwsteen en oriëntatiepunt, en erkenden zij meer rechtvaardige redenen voor oorlog dan slechts een zelfverdediging tegen agressie. Vaak werd een rechtvaardige oorlog gedefinieerd in termen van het rechtzetten van toegebrachte schade of onrecht. Qua voorgestelde substantiële normen, zo laten verschillende theoretici zien (Steinhoff 2012, Brown 2017, Reichberg 2018), hebben revisionisten juist veel gemeen met de 'traditionele' of 'orthodoxe' theoretici.

Als gevolg van dit inzicht in de historische parallellen worden kritische vragen gesteld: Op welke positie richt de revisionistische kritiek zich? En hoe vernieuwend zijn deze theoretici werkelijk? De zwakke punten in Walzers theorie kunnen ook worden blootgelegd door een historische benadering van de rechtvaardige oorlog ('de derde weg'), zo stelt Christian Braun. Een analyse van theoretici als Vitoria en Grotius maakt bijvoorbeeld duidelijk dat er pragmatische redenen zijn om combattanten gelijke rechten toe te kennen: het is vreselijk moeilijk om te bepalen welke combattanten een rechtvaardige oorlog bevechten, en daarom

\footnotetext{
${ }^{9}$ McMahan stelt: 'The doctrine of the moral equality of combatants (...) is almost universally accepted among those who are not pacifists, and has been for many centuries.' McMahan (2009: 38). Ook Rodin lijkt zijn kritiek te richten op de historische theorie van de rechtvaardige oorlog als geheel (Rodin 2006: 244).

${ }^{10}$ Voor James Pattison is 'orthodox' is een onjuiste betiteling, omdat hij stelt dat revisionisme hard op weg is de nieuwe orthodoxie te worden, in ieder geval in filosofische kringen.
} 
moeten beide zijden zich houden aan het jus in bello. Dit betekent echter niet dat zij moreel gelijk zijn (Braun 2018: 11). Tegenwoordig erkennen veel revisionisten de historische parallellen. ${ }^{11}$ Het is echter overduidelijk dat zij hun pijlen richten op Walzers theorie. Deze theorie is decennia lang de standaard geweest, en kan daarom conventioneel genoemd worden, verwijzend naar de heersende conventie.

De vraag naar het vernieuwende gehalte blijft spelen. In een recente discussie tussen Fabre en Uwe Steinhoff op de filosofische blog Peasoup gaf Fabre aan het oneens te zijn met de beschuldigingen aan haar adres dat 'zelfverklaarde revisionisten' eigenlijk niets weten over de historische wortels van hun opvattingen. Wij erkennen allemaal de traditionele claim dat combattanten niet mogen deelnemen aan onrechtvaardige oorlog, zo stelt Fabre. Steinhoff reageert als volgt:

By 'self-proclaimed' I mean, in line with the meaning that expression actually has, that it is not the case that some group of historians of just war theory looked at a certain group of recent just war theorists in awe and said: 'Gee, they are so incredibly innovative, we just have to call them "revisionary" but that, instead, you guys call yourself revisionary. That self-assessment would be quite acceptable if it were correct, but it is not, which brings me to the topic of ignorance. ${ }^{12}$

Hoe vernieuwend een bepaalde positie of argument is staat altijd ter discussie. Natuurlijk is het de bedoeling dat academici vernieuwend werk produceren, in ieder geval tot op zekere hoogte. Bezien in de huidige tijd is het revisionisme, als algemene stroming binnen de theorie van de rechtvaardige oorlog, zeer zeker vernieuwend. Maar de korte historische achtergrond maakt duidelijk dat het conventionalisme van Walzer dat label zelf ook verdient: zijn klassieker Just and Unjust Wars wijkt af van belangrijke onderdelen van de rijke historische traditie, en was ook uitermate vernieuwend in 1977. Zolang we dat echter erkennen, de historische paralellen onder ogen zien, en duidelijk aangeven waar de terminologie (niveau 1) naar verwijst, lijkt het niet principieel bezwaarlijk te spreken over conventionalisme en revisionisme binnen de theorie van de rechtvaardige oorlog.

\footnotetext{
${ }^{11}$ Meer dan parallellen zijn het ook niet: er zijn ook grote verschillen tussen de historische theorie en de revisionistische opvatting. Eén van die verschillen is natuurlijk het religieuze karakter van de historische theorie, en het seculiere karakter van de hedendaagse revisionistische theorie van de rechtvaardige oorlog.

12 Zie: http://peasoup.typepad.com/peasoup/2015/05/ethics-discussions-at-pea-soup-cecile-fabres-war-exit-withcritical-precis-by-helen-frowe.html (geraadpleegd 5-1-'19).
} 


\section{Theoretische verschillen}

Omdat de meeste discussies betrekking hebben op de substantiële verschillen tussen beide posities (i.e. de inhoud van de normen/niveau 2), wil ik hier bezien op welke theoretische uitgangspunten deze verschillen gebaseerd zijn (niveau 3). Hoe komen revisionisten tot hun (vernieuwende) conclusies ten aanzien van het juiste gedrag in en rondom oorlog? En hoe verschilt dat van de conventionele uitgangspunten? Dit inzicht maakt het mogelijk de twee posities op een juiste manier te doorgronden en evalueren. Deze onderliggende theoretische verschillen vormen aldus de basis voor de evaluatie van beide posities in de volgende secties. Ik begin met de conventionele uitgangspunten, om daarna te laten zien hoe de revisionistische uitgangspunten daarvan afwijken. ${ }^{13}$

De conventionele positie is gebaseerd op diverse theoretische premissen. Allereerst stelt de theorie staten centraal: niet alleen is de wereld opgebouwd op basis van soevereine staten, maar deze staten hebben een onafhankelijke morele status. Hoewel individuele mensenrechten belangrijk zijn, zijn collectieve rechten dat evenzo. Wat de soevereiniteit en territoriale integriteit van staten zo waardevol maakt is dat deze het recht van politieke gemeenschappen op autonomie en zelfbepaling mogelijk maken. Uiteindelijk echter, zijn de rechten van staten te herleiden tot individuele mensenrechten; dat maakt rechten van staten zo sterk en waardevol. De soevereiniteit van staten is dan ook niet absoluut. Staten verspelen hun claim op soevereiniteit in geval van extreme interne agressie; wanneer zij het collectieve recht op zelfbepaling en de basale rechten van hun burgers schenden. Ten tweede stelt de conventionele theorie dat oorlog een exceptioneel moreel domein is dat kwalitatief verschilt hoewel het er niet los van staat - van het normale leven. Hoewel de onderliggende normatieve principes hetzelfde zijn, kunnen en zullen de morele normen voor beide domeinen verschillen (vgl. Shue 2008: 88). Zo is bijvoorbeeld, anders dan in het normale leven, het doden van mensen toegestaan terwijl zij geen directe bedreiging vormen, e.g. etende soldaten (Walzer 2005 en Rodin 2002: 127, 128). Er bestaan verschillende redenen voor deze vorm van 'exceptionalisme': de omvang en de ernst van oorlog als gewapend conflict, de fundamentele politieke belangen die op het spel staan, de chaos, complexiteit en onzekerheid van oorlog (fog of war), en het feit dat basale morele normen (zoals de verplichting het recht op leven te respecteren) op grote schaal geschonden worden.

13 Deze sectie is een uitwerking van een soortgelijke analyse toegespitst op het probleem van hulpbronnenoorlogen in een recent verschenen artikel: Peperkamp \& Tinnevelt (2017: 2.1). 
De derde premisse heeft betrekking op de methodologie. De conventionele theorie maakt gebruik van een casuïstische methode. Er wordt uitgegaan van daadwerkelijke (historische) oorlogssituaties, en met de verschillende bronnen in het achterhoofd (rechtvaardige oorlogstheorie, juridische voorschriften, memoires en literatuur), worden alle morele afwegingen geanalyseerd. Het resultaat is een verhalende theorie die morele normen biedt welke voortvloeien uit morele intuïties, diverse bronnen, en verschillende ethische beginselen. De vierde premisse is dat de conventionele rechtvaardige oorlogstheorie prudentiële overwegingen in haar analyse van oorlog incorporeert. Ze houdt sterk rekening met wat praktisch mogelijk en haalbaar is (feasible) en probeert realistisch te zijn met betrekking tot wat er werkelijk bereikt kan worden in tijden van oorlog. Conventionalisten zoeken een balans tussen het wenselijke (met name het beschermen van rechten) en het realistische om zo de negatieve effecten van oorlog zoveel mogelijk te beperken.

Behalve dat de revisionisten gemeen hebben dat ze op enigerlei wijze de gevestigde normen willen herzien, baseren zij hun argumenten op grofweg gelijkaardige theoretische uitgangspunten. Deze premissen wijken af van de premissen waarop de conventionele theorie gebaseerd is. Ten eerste zijn individuen het object van primaire morele bekommernis en niet staten. Revisionisten zijn in die zin moreel individualisten; zij hechten minder waarde aan gemeenschappen dan de conventionalisten. Bovendien ontkennen ze de onafhankelijke morele status van staten. Staten zijn slechts instrumenteel waardevol voor zover zij bijdragen aan het individuele welzijn van de leden. De moraliteit van oorlog kan daardoor niet worden verklaard in termen van soevereiniteit en collectieve rechten, maar louter in termen van individuele rechten. ${ }^{14}$ Ten tweede bekritiseren ze de aanname dat oorlog een exceptioneel moreel domein is. De morele regels die de oorlog beheersen kunnen afgeleid worden uit de morele regels die het gewone leven bepalen. Oorlog moet dus worden beoordeeld aan de hand van onze 'normale' moraliteit. Dit 'reductivisme' betekent dat er geen duidelijke grens bestaat tussen rechtvaardige oorlogstheorie en algemene normatieve theorie; het domein van oorlog is niet kwalitatief anders dan andere domeinen in de werkelijkheid.

De derde premisse is daaraan gerelateerd en heeft betrekking op de methodologie. Revisionisten gaan uit van abstracte normatieve principes (meestal een deontologisch individueel rechtenkader) en testen deze door ze toe te passen op hypothetische voorbeelden, zowel geïdealiseerde reële situaties als compleet fictieve voorbeelden (bv. McMahan 1994,

\footnotetext{
${ }^{14}$ Hoewel Fabre bijvoorbeeld wel erkent dat gemeenschappen belang hebben bij collectieve zelfbeschikking en territoriale integriteit van de staat; dit komt de belangen van individuele leden van de gemeenschap ten goede. Fabre (2012: 283).
} 
Rodin 2002, Frowe 2016). Hieruit worden vervolgens morele normen van toepassing op oorlog afgeleid. Historische voorbeelden worden meestal bewust terzijde geschoven (bv. Frowe 2011: 2, Evans 2005: xi). Het resultaat is een systematische theorie die eerder logisch en rekenkundig van aard is dan verhalend. De vierde premisse is dat revisionisten over het algemeen veel idealistischer zijn dan traditionalisten. Ze doen minder concessies aan praktische beperkingen en komen vaak uit bij een tweeledige benadering die 'diepe' morele normen van pragmatische juridische normen probeert te onderscheiden. ${ }^{15}$

\section{Beoordelingskader}

In de voorgaande secties heb ik duidelijk gemaakt hoe we de twee posities in ideaaltypische zin kunnen karakteriseren, wat de belangrijkste verschillen zijn qua voorgestelde substantiële normen, hoe we deze posities kunnen noemen, en op welke onderliggende theoretische uitgangspunten ze zijn gebaseerd. Er zullen lezers zijn die op basis van persoonlijke smaak, theoretische achtergrond of overtuigingskracht reeds een duidelijke voorkeur voor een bepaalde positie hebben. Echter, om dit goed te kunnen beoordelen moeten we de theoretische uitgangspunten bezien in een bredere context. Waar moet een morele theorie in algemene zin eigenlijk aan voldoen om een goede theorie te zijn? Bovendien moeten we de bijzondere rol en functie van de theorie van de rechtvaardige oorlog in ogenschouw nemen. In deze sectie benoem ik een aantal algemene criteria voor de beoordeling van morele theorieën, geef ik aan wat voor type theorie de theorie van de rechtvaardige oorlog is, en welke criteria daardoor extra aandacht verdienen. Deze sectie vormt zo het beoordelingskader voor de beide posities in de volgende secties.

Hoe kan de mens juist handelen? Een morele theorie vormt een gedragscode die aangeeft welk gedrag verboden, geoorloofd of geboden is. ${ }^{16}$ Mensen kunnen 'het juiste' of 'het goede' doen wanneer zij hun gedrag afstemmen op de voorgeschreven morele normen. Een morele theorie functioneert als een test; het helpt te bepalen wat moreel juist en onjuist is, rechtvaardig en onrechtvaardig, goed en slecht. Maar hoe testen we de test, i.e. de morele theorie? Wat maakt een theorie een plausibele, adequate, een juiste theorie? In het algemeen wordt een theorie positief beoordeeld wanneer voldaan wordt aan een aantal vereisten. In de

\footnotetext{
${ }^{15}$ Zie verder over de relatie tussen de moraliteit van oorlog en het oorlogsrecht bijvoorbeeld: McMahan 2010, Shue 2010, Lazar 2018, Buchanan 2018, Waldron 2018.

${ }^{16}$ Of volgens Lansing Pullock: 'Let us understand a moral theory to be a systematic account of moral thought and practice which (supposedly) provides a general test for determining what is morally right or wrong.' Pullock (1988: 229).
} 
literatuur worden verschillende vereisten voorgeschreven die in zekere mate vergelijkbaar zijn. De criteria die ik hier als leidraad gebruik zijn gebaseerd op de meest gebruikte testen. ${ }^{17}$ Een morele theorie moet idealiter voldoen aan de volgende criteria:

A) Coherentie en consistentie: de verschillende onderdelen van de theorie moeten met elkaar overeenstemmen, en de conclusies moeten logisch volgen uit de argumenten en onderliggende principes. Bovendien moeten de voorgestelde normen samen met relevante feitelijke informatie consistente (en geen tegenstrijdige) morele oordelen opleveren.

B) Verklarende kracht: de theorie moet kunnen aangeven en verklaren waarom bepaalde gedragingen juist of onjuist zijn. Het moet duidelijk zijn op welke algemene normatieve principes de normen gebaseerd zijn. Waarom moeten we de normen accepteren? Wat is, met andere woorden, de rechtvaardiging?

C) Plausibiliteit: de theorie moet plausibele normen voorschrijven die overeenstemmen met de morele intuïties van mensen met verschillende visies op de wereld. Wil een morele theorie richting kunnen geven aan gedrag, dan zullen de normen begrijpelijk en acceptabel moeten zijn voor de mensen waarop de theorie van toepassing is. De normen moeten aldus algemeen aanvaardbaar zijn en geaccepteerd kunnen worden door een grote groep mensen.

D) Toepasbaarheid: de theorie moet praktische waarde hebben in het hier en nu, relevant zijn voor de betreffende kwestie, en richting kunnen geven aan gedrag in concrete situaties. De theorie moet daartoe normen bieden die gevolgd kunnen worden door relevante actoren, en die hen kunnen helpen bij het maken van morele beslissingen.

Deze criteria corresponderen met twee centrale doelstellingen van een morele theorie. De theoretische doelstelling is gericht op het beantwoorden van abstracte vragen ten aanzien van de manier waarop iets goed of slecht is. Dergelijke antwoorden bieden een theoretisch inzicht in het morele oordeel (consistentie, verklarende kracht, plausibiliteit). ${ }^{18}$ De praktische doelstelling is gericht op het bepalen van het juiste gedrag in een concrete context

\footnotetext{
${ }^{17}$ Om een aantal voorbeelden te noemen: Pullock (1988): verklarende kracht, simpelheid, coherentie, en empirische inhoud; Timmons (2013): consistentie, determinatie, toepasbaarheid, interne steun, externe steun, en verklarende kracht; Harris (1997): consistentie, praktische waarde, rechtvaardiging; Pattison (2018): determinatie, relevantie, plausibiliteit, brede aantrekkingskracht. Zie ook: List en Valentini (2016).

${ }^{18}$ Plausibiliteit ondersteunt beide doelstellingen.
} 
(plausibiliteit, toepasbaarheid). ${ }^{19}$ Afhankelijk van het type morele theorie ligt de nadruk op een bepaalde doelstelling en daarmee verbonden criteria. Meta-ethische theorieën hebben betrekking op de oorsprong en betekenis van ethische concepten, en zijn aldus uitermate abstract van karakter. Algemene ethische theorieën - zoals utilitarisme, deontologie, deugdethiek en sociale contract theorie - bieden theoretisch inzicht maar zijn ook gericht op het formuleren van een algemene morele maatstaf voor moreel handelen. Toegepaste ethische theorieën zijn gericht op het beantwoorden van praktische vragen ten aanzien van de manier waarop iets goed of slecht is in een bepaalde situatie. Dergelijke theorieën geven een normatieve beoordeling van maatschappelijke onderwerpen, en proberen voor die onderwerpen concrete richtlijnen, dus meer specifieke normen, vast te stellen. Daartoe worden algemene normatieve principes vertaald teneinde toegepast te kunnen worden op bepaalde controversiële kwesties, thema's of omstandigheden. Voorbeelden van toegepaste ethische theorieën zijn rechtsfilosofie, politieke filosofie, filosofie van dierenrechten, medische ethiek, bedrijfsethiek, de ethiek van zelfdoding, en klimaatrechtvaardigheid.

De theorie van de rechtvaardige oorlog is ook een voorbeeld van een toegepaste ethische theorie. Het is geen algemene ethische theorie, maar een morele theorie toegepast op de situatie van oorlog. Wat is het juiste gedrag ten aanzien van oorlog, oorlogvoering, en wederopbouw na de oorlog? Voor een dergelijke toegepaste ethische theorie is het belangrijk dat de relatie met de algemene ethische theorie duidelijk wordt gemaakt. De theorie moet verklaren op welke abstracte normatieve principes zij gebaseerd is. ${ }^{20}$ Wat is de rechtvaardiging voor de normen? Welke leidende principes worden gekozen? Een toegepaste ethische theorie staat niet op zichzelf, maar heeft een helder normatief kader nodig dat werkt als fundering. Een dergelijk kader specificeert coherente principes en de hiërarchie daartussen zodat duidelijk is waar de praktische richtlijnen uit voortkomen. Een toegepaste ethische theorie kan, met andere woorden, niet zonder een meer abstract normatief kader. De theoretische doelstelling speelt aldus een wezenlijke rol.

Het is bovendien de bedoeling dat de theorie een gedragscode biedt; morele normen in de vorm van praktische richtlijnen van toepassing op de realiteit van oorlog. Een gedragscode die kan helpen bij het maken van de moeilijke beslissingen waar politieke leiders en combattanten mee te maken krijgen: Wanneer beginnen we een oorlog? Wie mag ik doden? Hoeveel

\footnotetext{
19 Timmons (2013).

${ }^{20}$ Sommige theoretici zijn hier heel sterk in, en laten duidelijk zien op welke algemene normatieve theorie hun toegepaste theorie gebaseerd is: Fabre's theorie op het moreel kosmopolitisme (Fabre 2012, 2016), Shaw op het utilitarisme (Shaw 2016), Lee op individuele mensenrechten (Lee 2012), Luban specifiek op individuele basisrechten (Luban 1980a 1980b), en Rawls en Benbajij op een vorm van sociale contracttheorie (Rawls 1999 en Benbaji 2011).
} 
burgerslachtoffers zijn acceptabel? En welke verplichtingen zijn er in de nasleep van oorlog? In het algemeen is de theorie van de rechtvaardige oorlog erop gericht menselijk lijden zoveel mogelijk te beperken door het aantal oorlogen en het geweld in oorlog te beperken tot dat wat strikt noodzakelijk is. ${ }^{21}$ Gezien de rol die de theorie van de rechtvaardige oorlog vervult staat de praktische doelstelling aldus centraal, terwijl de gedragscode gegrond zou moeten zijn in een normatief kader dat de specifieke normen uitlegt en rechtvaardigt. Alexander Moseley besluit de Just War Theory entry in de Internet Encyclopedia for Philosophy met deze opmerking: 'The theory bridges theoretical and applied ethics, since it demands an adherence, or at least a consideration of meta-ethical conditions and models, as well as prompting concern for the practicalities of war. ${ }^{22}$ Voor een volledige, complete en overtuigende theorie van de rechtvaardige oorlog zijn beide doelstellingen essentieel. Uiteraard vormt daarnaast het recht een belangrijke bron van normen in deze context. Daarmee kan gezegd worden dat er drie normenstelsels van toepassing zijn op de praktijk van oorlogsvoering: 1) algemene ethische theorie (abstracte normatieve principes), 2) toegepaste ethische theorie, en 3) het recht.

\section{Algemene beschouwing}

Hoe moeten beide posities - conventionalisme en revisionisme - geëvalueerd worden in het licht van dit beoordelingskader? Oftewel, wat zijn de voor- en nadelen van beide posities, afgemeten aan deze vier criteria en de speciale de rol van de theorie in aanmerking nemende? In deze sectie beschouw ik eerst in algemene zin hoe de posities zich verhouden tot de verschillende criteria. Wanneer we de uitgangspunten en de substantiële normen in het licht van deze criteria beschouwen, wordt duidelijk dat beide posities het debat iets waardevols te bieden hebben. Dit betekent ook dat men van elkaar kan leren: inzicht in elkaars sterke en zwakke punten kan gebruikt worden door vertegenwoordigers van beide posities om op verschillende manieren hun theorie te versterken en verbeteren. In de volgende sectie geef ik aan waarom deze verbeteringen nodig zijn, door de posities te beoordelen in het licht van de speciale rol van de theorie van de rechtvaardige oorlog. Alvorens dat te doen behandel ik hier achtereenvolgens de vier algemene criteria.

\footnotetext{
${ }^{21}$ Of dat nu geformuleerd wordt in termen van geschonden rechten, menselijk lijden, of een afname van menselijk welzijn. Zie discussie over deze algemene doelstelling Shue (2010: 515) en Lazar (2018).

${ }^{22} \mathrm{Zie:} \mathrm{https://www.iep.utm.edu/justwar/} \mathrm{(geraadpleegd} \mathrm{5-1-'19).}$
} 
Coherentie en consistentie: Revisionisten zijn zeer gericht op het voortbrengen van een coherente theorie van de rechtvaardige oorlog. Coates stelt in dit verband: 'The method puts the dominant theory to the test through sustained conceptual analysis, exposing its logical flaws and, where appropriate, amending or replacing it with a theory that is clearer, more rigorous and coherent (...) (2016: 6). Revisionisten bijten door de zure appel heen als dat nodig is en accepteren soms controversiële conclusies teneinde de coherentie van hun theorie te bewaken. Dat kan betekenen dat zij eindigen bij een contingent pacifistisch standpunt of dat bepleit wordt dat het humanitair oorlogsrecht aangepast moet worden om individuele morele aansprakelijkheidsregels te weerspiegelen (Rodin 2011).

In hun kritiek op de conventionele positie leggen revisionisten de vinger op de zere plek. De conventionele theorie is filosofisch incoherent, zo stellen zij. En inderdaad, het is duidelijk dat de theorie op dit onderdeel van de test minder goed scoort. Laat me twee voorbeelden geven. Rodin's invloedrijke kritiek laat zien waarom Walzers argument voor nationale zelfverdediging incoherent is (Rodin 2002, 2018). Dit argument is gebaseerd op een analogie tussen collectieve en individuele zelfverdediging (zonder het eerste te reduceren tot het laatste). Walzer stelt dat tegen agressie, gedefinieerd als 'elke schending van de territoriale integriteit en politieke soevereiniteit van een onafhankelijk land', gewelddadig verzet gerechtvaardigd is (Walzer 2006: 97). Deze claim is in lijn met het internationaal recht. Echter, zo stelt Rodin, het wordt vaak aangenomen dat het bedreigde individu zich terug moet trekken als dat mogelijk is, en zo zijn of haar leven te redden zonder zelf geweld te gebruiken. Hoewel Walzer dus stelt dat tegen elke vorm van agressie verdediging gerechtvaardigd is, volgt dat niet uit deze analogie. Een land dat bijvoorbeeld te maken krijgt met een agressor die 'slechts' een vruchtbaar stuk land wil annexeren, kan gemakkelijk slachtoffers voorkomen zonder zelf geweld te gebruiken, namelijk door te voldoen aan de conditionele agressie en het gebied af te geven (Rodin 2002: hfdst. 6). Het afleiden van een algemeen recht op zelfverdediging uit een analogie met individuele zelfverdediging lijkt aldus niet coherent. ${ }^{23}$

Een tweede zeer invloedrijke kritiek heeft betrekking op het jus in bello, meer specifiek de morele gelijkheid van combattanten. Onrechtvaardige combattanten hebben niet dezelfde rechten wanneer het oorlogsgeweld is losgebarsten, zo stellen revisionisten. Zij kunnen namelijk nooit voldoen aan het proportionaliteitscriterium, dat bepaalt dat collateral damage slechts te rechtvaardigen is als het onrecht van burgerslachtoffers teniet wordt gedaan door het grote militaire voordeel dat ermee wordt behaald. Dergelijke militaire doelen zijn niet

\footnotetext{
${ }^{23}$ Het is de vraag of deze analogie volgens Walzer helemaal opgaat.
} 
neutraal; zij zijn onderdeel van een militaire strategie die gericht is op het bereiken van een bepaald doel, in het algemeen het winnen van de oorlog. Maar als die oorlog onrechtvaardig is, dan is dat doel ook onrechtvaardig en kan het militaire voordeel dat het doel helpt te realiseren het onrecht van burgerslachtoffers niet compenseren (McMahan 1994, 2004, Rodin 2002, Hurka 2005). In de utilitaristische calculus van de proportionaliteit ligt er alleen 'kwaad' in de weegschaal - burgerslachtoffers en een militaire bijdrage aan een onrechtvaardige oorlog - zonder dat er iets 'goeds' aan de andere kant ligt. Eigenlijk, zo stelt bijvoorbeeld McMahan, kunnen onrechtvaardige combattanten nooit op een proportionele manier vechten. Daarom hebben combattanten in oorlog dan wel dezelfde juridische rechten, die gelijkheid kan niet gerechtvaardigd worden door objectieve morele normen (zie ook Lazar 2017a: 116). Deze twee welbekende kritieken laten zwakheden zien in Walzers argumentatie. In zekere zin erkent Walzer dit. Hij geeft bijvoorbeeld toe dat de morele gelijkheid van combattanten wellicht de meest vreemde regel is van de oorlogsconventie, zeker wanneer dit bekeken wordt vanuit het perspectief van de morele theorie en niet de praktijk van oorlog (Walzer 2015: 346). ${ }^{24}$

Verklarende kracht: Ook ten aanzien van de verklarende kracht staat de conventionele positie niet al te sterk. De inzet van Walzers werk is niet gericht op het stevig funderen van de praktische richtlijnen (Walzer 2006: 26). Qua fundering lijkt zijn theorie op een samenraapsel van principes uit verschillende algemene ethische theorieën. ${ }^{25}$ Dit fundament blijft echter grotendeels impliciet: het is vaak niet duidelijk op welke normatieve principes de normen gebaseerd zijn. Hoe worden de normen die hij voorstelt gerechtvaardigd? Kijkend naar het jus ad bellum, lijkt de rechtvaardige reden gegrond te zijn op een deontologisch idee van het beschermen van individuele rechten en de rechten van een politieke gemeenschap; de criteria van het laatste redmiddel, proportionaliteit en noodzakelijkheid op een consequentialistische afweging van (waarschijnlijke) gevolgen van het wel of niet beginnen van de oorlog; en de juiste intentie op een deugd-ethisch idee van het hebben van een oprechte houding in lijn met de rechtvaardige reden voor oorlog. ${ }^{26}$ Walzer zelf noemt zijn theorie 'in filosofische vorm een leer van de mensenrechten' (Walzer 2006: 27), maar dat is zeker geen eenduidige verklaring van de normen die hij voorstelt. Rechten van non-combattanten mogen bijvoorbeeld

\footnotetext{
${ }^{24}$ Er zijn uitvoerige debatten gevoerd over beide lijnen van kritiek, maar met deze korte uiteenzetting heb ik hopelijk voldoende kunnen laten zien waar zwakke plekken qua coherentie te vinden zijn. Walzers belangrijke tegenargument, wat we ook terugzien bij bijvoorbeeld Shue, is het exceptionalisme dat hij onderschrijft. Ik kom daar later in deze sectie nog op terug.

${ }^{25}$ Zie ook Fotion (2014: 93, 94).

${ }^{26}$ Coates stelt zelfs dat de conventionele theorie een 'character-based approach' is in tegenstelling tot de revisionistische 'rule-based approach'. (2016: 11,12).
} 
geschonden worden; zolang ze maar geen direct doelwit zijn is collateral damage acceptabel. De non-combattanten immuniteit (oftewel de rechten van onschuldige individuen) is aldus niet absoluut; dat zou betekenen dat oorlogsvoering onmogelijk zou worden en dit wil Walzer vermijden. Wat betekent dit voor de verklarende kracht van de conventionele rechtvaardige oorlogstheorie? Een theorie zou goed op dit testonderdeel scoren wanneer het de voorgestelde normen kan verklaren op basis van zo weinig en helder mogelijke normatieve principes. ${ }^{27} \mathrm{En}$ Walzer lijkt juist voor elke norm en voor verschillende situaties andere verklarende principes nodig te hebben. Het is zeker geen theorie die slechts vanuit een strikt mensenrechtenkader verklaard kan worden.

In dit opzicht lijkt de revisionistische positie sterker. In ieder geval leggen revisionisten veel meer nadruk op de verklarende kracht van hun theorie. Zij maken meestal zeer duidelijk op welke normatieve principes hun theorie gebaseerd is (e.g. Draper 2016, Fabre 2012, 2016, Frowe 2014, Benbaji 2011). Zij vertrekken vanuit een abstracte algemene ethische theorie van waaruit kritiek wordt geleverd op de conventionele positie, en van waaruit alternatieve normen voor oorlog logischerwijs en vaak zeer systematisch worden afgeleid. Prudentiële overwegen worden vrijwel niet meegenomen. De conventionele normen van het jus in bello zijn onjuist, zo stellen bijvoorbeeld Rodin, McMahan, Frowe en anderen, omdat een strikt deontologische systematiek van individuele rechten (e.g. zoals Hohfeld's schema, met name het recht op zelfverdediging en de manieren waarop het recht op leven verloren kan worden) dat uitwijst (Rodin 2002, McMahan 2004).

Fabre laat ook zien hoe sterk de verklarende kracht van de revisionistische positie kan zijn. Zij stelt dat haar hele theorie van de rechtvaardige oorlog voortvloeit uit de algemene morele theorie van het kosmopolitisme. Individuen zijn haar focus; haar theorie is zowel individualistisch als reductivistisch: de morele normen die van toepassing zijn op oorlog zijn een continuering van de normen die van toepassing zijn buiten oorlog. We kunnen de ethiek van oorlog aldus begrijpen door te kijken naar individuele situaties in het normale leven; er is geen exceptionele ethiek van oorlog. Collectieve zelfverdediging van staten tegen militaire agressie is te reduceren tot individuele zelfverdediging tegen een onrechtvaardige levensbedreiging. Vervolgens bouwt Fabre haar theorie op één helder verklarend principe: alle mensen hebben recht op de vrijheden en middelen die nodig zijn om een minimaal fatsoenlijk (Fabre 2012) of zelfs een bloeiend (Fabre 2016) leven te leiden, waar ter wereld ze ook leven. Fabre's rechtvaardige oorlogstheorie is daarmee een voorbeeld van de sterke

\footnotetext{
${ }^{27}$ Harsanyi (1982: 389).
} 
verklarende kracht van de revisionistische positie, waarbij veel aandacht wordt geschonken aan het zeer precies en duidelijk aangeven wat de rechtvaardiging is voor de normen die verdedigd worden.

Plausibiliteit: Ten aanzien van de plausibiliteit van de theorie is duidelijk dat beide posities sterk vertrouwen op morele intuïties. Echter, de methodologie laat zien dat de casussen, ofwel de situaties waarin de morele intuïties worden gedestilleerd (de zogenaamde intuition pumps), verschillen: vanuit het exceptionalisme analyseren conventionele theoretici over het algemeen concrete historische oorlogssituaties die dit exceptionele domein weerspiegelen, terwijl revisionisten geïdealiseerde of geheel fictieve individuele situaties uit het gewone leven analyseren, omdat de moraliteit van oorlog een continuering is van de 'normale moraliteit'. Bovendien lijkt het doel anders te zijn: voor Walzer is de overeenkomst met morele intuïties nodig voor de effectiviteit van de theorie (de praktische doelstelling), terwijl bij revisionisten de intuïties moeten bewijzen dat de theorie in abstracte zin juist en coherent is (de theoretische doelstelling). Hierop kom ik in de volgende sectie nog uitgebreid terug. Het is hier de vraag welke manier van intuïties destilleren de meest plausibele theorie oplevert.

Het gaat Walzer om 'onze' morele intuïties, waarbij 'ons' verwijst naar het merendeel van de mensheid (Walzer 2006: 25, 26). Hij appelleert aan ons gezonde verstand (commonsense morality); de vorm van moraliteit die dagelijks door mensen wordt toegepast zonder daar heel diep over na te denken. Walzer wekt intuïties op (i.e. maakt ons bewust van ons gezonde verstand) en test de verschillende algemene principes door te kijken naar daadwerkelijke oorlogssituaties waarin zich ethische dilemma's voordoen. Een voorbeeld van een dergelijke casus is het gedrag van de Duitse generaal Erwin Rommel, die aan een onrechtvaardige oorlog deelnam maar weigerde om Hitlers bevel op te volgen en gevangenen dood te schieten. Walzer, en 'iedereen die hierover heeft geschreven', ziet hem desondanks als eervol: 'hij voerde een smerige oorlog op een fatsoenlijke manier' (Walzer 2006: 80-83). Dergelijke intuïties ondersteunen volgens Walzer de morele gelijkheid van combattanten. Omdat Walzer het belangrijk vindt dat deze normen daadwerkelijk worden nageleefd - teneinde oorlog en leed te verminderen - moeten ze plausibel zijn en dus algemeen geaccepteerd kunnen worden, met name door de betrokkenen die de normen moeten toepassen. ${ }^{28}$

Revisionisten appelleren ook aan ons gezonde verstand, maar gebruiken andere situaties om intuïties op te wekken. Hierdoor trekken ze tegengestelde conclusies, bijvoorbeeld met

\footnotetext{
28 'Het ethische gezichtspunt ontleent zijn legitimiteit dus aan het perspectief van de betrokkene.' (Walzer 2006:
} 40). 
betrekking tot het jus in bello. Voor revisionisten is het ondenkbaar dat iemand als Rommel eervol of moreel juist handelt. Voor McMahan is Rommel te vergelijken met een inbreker die zich aan bepaalde regels houdt wanneer hij inbreekt, bijvoorbeeld door de bewoners niet onnodig te verwonden, het huis niet in brand te steken en de huisdieren niet te martelen. Natuurlijk is het beter dat de inbreker die dingen niet doet, maar dat maakt zijn handelen niet rechtvaardig en hemzelf niet eervol. Of hij nou wel of niet de hond martelt, daar gaat het eigenlijk niet om, hij doet iets compleet immoreels door in te breken en dat zou hij niet moeten doen (McMahan 2006). Als het doel onrechtvaardig is zijn de middelen om dat doel te bereiken dat ook. De hypothetische voorbeelden (geïdealiseerde echte situaties of compleet fictieve situaties) overwegend, is de revisionistische positie ook plausibel en bovendien coherent met onze ideeën over hoe men rechtvaardig of onrechtvaardig handelt in het dagelijkse leven. Net als conventionalisten, lijken revisionisten een plausibele morele theorie te schetsen.

De vraag stelt zich dus: welke intuïties zijn de juiste? Met andere woorden, welke methodologie levert de meest plausibele theorie op? Het is de vraag of revisionisten uit hypothetische voorbeelden, ver verwijderd van de realiteit van oorlog, een plausibele rechtvaardige oorlogstheorie kunnen deduceren. ${ }^{29}$ Ongeacht of men het exceptionalisme of reductionisme onderschrijft, valt niet te ontkennen dat er een groot verschil is tussen de hypothetische voorbeelden en de complexe realiteit van oorlog. In die realiteit zijn combattanten bijvoorbeeld verplicht de bevelen van hun meerderen op te volgen, en dit stemt overeen met zowel hun morele intuïties als die van veel anderen. Het gebruik van hypothetische intuition pumps staat ter discussie (O’Neill 1996, Dennett 2013, Elster 2011, List \& Valentini 2016, Brownlee \& Stemplovska 2017). ${ }^{30}$ Bovendien moet erkend worden dat intuïties in individuele hypothetische situaties niet altijd overeenstemmen met dezelfde intuïties in werkelijke situaties waarop de afgeleide normen van toepassing moeten zijn. In hypothetische situaties worden bepaalde relevante variabelen geïsoleerd en blijft alles wat niet meegenomen moet worden in de beoordeling buiten beeld; de bekende strategie to keep all else equal. Maar wat als er belangrijke contextuele omstandigheden worden geïdealiseerd, en bepaalde eigenschappen van het fenomeen oorlog worden uitgesloten die gewoonweg altijd aanwezig zijn in de praktijk?

\footnotetext{
${ }^{29}$ Zie Walzers reactie op McMahan: (Walzer 2006: 43).

${ }^{30}$ Dergelijke voorbeelden kunnen op een bepaalde manier geframed zijn, waardoor ze vooroordelen opwekken, en de opgewekte intuïties daardoor minder betrouwbaar. Zo impliceren de voorbeelden van de 'tactical bomber' en de 'terrorist bomber' al onmiddellijk wie de rechtvaardigheid aan zijn zijde heeft.
} 
Fabre bijvoorbeeld verdedigt de mogelijkheid van rechtvaardige subsistence wars: oorlogen van de armen tegen de rijken om hun recht op een behoorlijke levensstandaard te claimen. Door hypothetische voorbeelden te overwegen lijkt dit een plausibele claim. Echter, in de echte wereld zijn de hypothetische omstandigheden (vrijwel) nooit aanwezig. Fabre erkent dit ook: 'in the light of the foregoing considerations, one might think that a subsistence war would never be just - perhaps almost per definition' (2012: 118). Het recht op het voeren van een subsistence war is, met andere woorden, niet plausibel omdat het in de echte wereld nooit kan leiden tot een rechtvaardige oorlog; een dergelijke oorlog is nooit proportioneel of succesvol. ${ }^{31}$ In de werkelijkheid heeft dat wat gefilterd wordt een onmiskenbare invloed. Hoewel hypothetische voorbeelden, i.e. gedachtenexperimenten zoals het welbekende trolley dilemma of de falling fat man, waardevolle inzichten kunnen bieden, lijkt mij een blind vertrouwen in dergelijke intuition pumps onwenselijk. Om zeker te weten dat de substantiële normen van een rechtvaardige oorlogstheorie plausibel en toepasbaar zijn, moeten deze normen en de principes waarop ze gebaseerd zijn ook getest worden in de complexe praktijk. Dit doen revisionisten over het algemeen niet en zij streven dat vaak ook niet na. ${ }^{32}$

Toepasbaarheid: Ten aanzien van de relevantie en praktische toepasbaarheid scoort de conventionele positie een stuk sterker dan de revisionistische positie. Het is duidelijk Walzers doel om praktische richtlijnen te formuleren waar soldaten in the fog of war iets aan hebben. Richtlijnen die ervoor zorgen dat oorlog en het gerelateerde menselijk lijden zoveel mogelijk wordt beperkt (zie ook Shue 2008). En terwijl McMahan aangeeft dat de revisionistische kritiek voortkomt uit het veranderde karakter van oorlogvoering, waarop de conventionele staat-gecentreerde theorie van de rechtvaardige oorlog niet goed van toepassing zou zijn, ${ }^{33}$ is juist deze uitwerking van de theorie slecht van toepassing op de realiteit van oorlog. Dat komt met name door de theoretische uitgangspunten van het revisionisme. Zoals hiervoor al duidelijk werd, ontkennen revisionisten dat oorlog een exceptioneel moreel domein is; de normen voor oorlog worden afgeleid uit algemene ethische theorieën en door gebruik van hypothetische individuele voorbeelden. Daardoor is de theorie per definitie minder context gevoelig dan het conventionalisme. Bovendien is het uitgangspunt een puur individualistisch model. Het is natuurlijk duidelijk dat het aantal klassieke interstatelijke oorlogen (tussen de professionele legers van twee staten) afneemt. Echter, door oorlogsvoering door een puur

\footnotetext{
${ }^{31}$ Ook Lippert-Rasmussen geeft aan dat het heel erg onwaarschijnlijk is dat zijn claim opgaat in de wereld zoals wij die kennen, en dat dit invloed heeft op de relevantie van zijn argument voor subsistence wars (LippertRasmussen 2017: 462).

${ }^{32}$ Zie ook Rigstad (2017).

${ }^{33} \mathrm{Zie}$ https://opinionator.blogs.nytimes.com/2012/11/11/rethinking-the-just-war-part-1/ (geraadpleegd 5-1-'19).
} 
individualistische bril te zien, wordt het collectieve karakter van oorlog miskent. Oorlog wordt vrijwel altijd gedefinieerd in termen van een gewapend conflict tussen twee of meer staten of politieke groepen. ${ }^{34}$ Het is een collectieve onderneming waarbij de rol van het individu beperkt is. Het is niet zo er geen moreel relevante verschillen zijn tussen een oorlog en een gewapend conflict tussen een aantal indianen (Steinhoff 2007). En het is ook onwaarschijnlijk dat een oorlog gelijk te stellen is met de bij elkaar opgetelde individuele aanvallen en zelfverdedigingsacties van combattanten (McMahan 2004).

Om dit collectieve karakter te illustreren kunnen we de rol van combattanten in oorlog bekijken. In oorlog zijn combattanten onmiskenbaar deel van een collectief met een sterke hiërarchische structuur, waarbij er weinig ruimte is voor individuele besluitvorming. Zij zien zichzelf en elkaar niet als individuen die zichzelf verdedigen wanneer zij worden bedreigd. Zij voelen zich onderdeel van een hecht collectief - hun peloton, compagnie, bataljon, divisie, en het gehele korps - en zij zijn getraind en gedrild om zowel elkaar als hun vaderland te verdedigen. Zij vechten ter bescherming van fundamentele politieke (en collectieve!) waarden. Deze sterke organisatie, structuur, en loyaliteit aan het vaderland zijn bovendien nodig om effectieve oorlogsvoering mogelijk te maken. De stabiliteit, efficiëntie en kracht van het leger berusten op de loyaliteit en gehoorzaamheid van de combattanten: ze zorgen voor hun kameraden, ze gehoorzamen hun meerderen, ze hebben zich gecommitteerd aan het leger. ${ }^{35}$ Het lijkt er dus op dat er uit dit individualisme normen worden afgeleid die niet goed passen bij de werkelijkheid.

Dit wordt versterkt door het idealisme van het revisionisme. Doordat pragmatische overwegen niet geïncorporeerd worden, gaan revisionisten meer richting een ideale theorie (hoewel het geen strikt ideale theorie is: de omstandigheid van oorlog betekent natuurlijk dat de omstandigheden niet ideaal zijn en strikt ideale normen niet zijn opgevolgd ${ }^{36}$ ). Over het algemeen worden er weinig beperkingen uit de werkelijkheid meegenomen in de formulering van de theorie. Er worden bijvoorbeeld hoge eisen aan combattanten gesteld: zij zijn individueel verantwoordelijk voor hun gedrag, moeten nagaan of zij zich wel inzetten voor

\footnotetext{
${ }^{34}$ Algemeen geaccepteerde definities stellen vast dat het bij oorlog gaat om georganiseerd, grootschalig geweld tussen militaire organisaties (Black 2007: 43) of een duurzaam conflict tussen gewapende groepen dat minimaal 1000 slachtoffers per jaar veroorzaakt (Correlates Of War Project, versie 4, 2010) Orend definieert oorlog als volgt: 'an actual, intentional, and widespread armed conflict between political communities' (Orend 2013: 2) Er is een consensus dat individuele geweldpleging niet voldoende is om te spreken van oorlog. Zie verder: http://cow.dss.ucdavis.edu/ (geraadpleegd 5-1-'19). Zie ten aanzien van het veranderde karakter van oorlog: Creveld 1991 en Kaldor 1999.

${ }^{35}$ De plicht tot gehoorzaamheid is niet alleen een pragmatische plicht, maar ook een morele plicht die voortkomt uit 'their obligation to their institution: they have committed themselves to fight for the military, and morality requires them to fulfill this commitment.'

${ }^{36}$ Zie Evans 2005 en Pattison (2018: 245).
} 
een rechtvaardige oorlog en moeten in een oorlog onderscheid maken tussen legitieme doelen en illegitieme doelen. ${ }^{37}$ Dergelijke gereviseerde jus in bello normen mogen dan filosofisch coherent zijn, ze zijn ook moeilijk toepasbaar. Hebben soldaten wel genoeg kennis van de politieke dynamiek om te kunnen beoordelen of hun oorlog rechtvaardig is? Is die kennis überhaupt voor het grote publiek beschikbaar? En kunnen combattanten in de extreme omstandigheden van oorlog - gekenmerkt door stress, doodsangst, tijdsdruk, beperkte mogelijkheden tot rationele besluitvorming - dergelijke afwegingen wel maken? Door verschillende empirische en epistemologische beperkingen lijkt het in de praktijk bijna onmogelijk om het revisionistische onderscheid maken: slechts de fictieve alwetende soldaat weet wat een legitiem doel is in oorlog. ${ }^{38}$ En als het niet kan heeft het ook geen zin dat van ze te verlangen. In oorlog geeft de revisionistische theorie dan ook onvoldoende richting, waardoor het minder relevant is voor de oorlogspraktijk. Het gereviseerde jus in bello is te gecompliceerd en moeilijk om direct te integreren.

In deze sectie heb ik een beoordeling van beide posities gegeven aan de hand van het evaluatiekader dat ik in de vorige sectie heb geschetst. Ik heb laten zien dat beide posities hun eigen sterktes en zwaktes kennen. Conventionalisten scoren goed op praktische toepasbaarheid en plausibiliteit van de theorie, maar kunnen wat leren van revisionisten als het gaat om de coherentie en de verklarende kracht. Revisionisten scoren uitstekend op coherentie - voor analytische filosofen hun 'vak', als het ware - en maken bovendien duidelijk welke normatieve principes de voorgestelde normen verklaren. Echter, de revisionistische theorie boet in als het gaat om de plausibiliteit, relevantie en toepasbaarheid van de theorie.

\section{Specifieke beoordeling}

Deze korte vergelijking in ogenschouw nemende en terugdenkend aan de twee doelstellingen van een morele theorie (theoretisch en praktisch), is het duidelijk dat conventionalisten en revisionisten een totaal verschillende focus hebben. Beide posities streven een ander doel na. Als gevolg daarvan houden zij zich elk met een ander soort theorievorming bezig. De identificatie van zwakke plekken in de vorige sectie vormt daarom geen doodsteek. De

\footnotetext{
${ }^{37}$ Dat betekent dat sommige combattanten niet mogen worden aangevallen, maar anderen en wellicht sommige schuldige burgers wel. Hoewel bijvoorbeeld McMahan stelt dat, gezien de moeilijkheid vast te stellen welke burgers moreel schuldig zijn en aldus legitieme doelen, het beter is voor soldaten om zich in dat opzicht aan het humanitair oorlogsrecht te houden. Er is aldus een verschil tussen de rechtvaardiging en toepassing van een morele regel.

${ }^{38}$ Zie voor een soortgelijk argument Dill 2018.
} 
analyse laat zien dat beide posities - gezien hun doelstelling en focus - gericht zijn op andere testonderdelen. Door duidelijk te maken waar ze zich wel of niet op richten, ondervangen zij beide de voornaamste kritiek.

De conventionalisten richten zich op de praktische doelstelling. Zij gaan uit van de concrete omstandigheden van oorlog en wegen verschillende handelingsmogelijkheden af die zich voordoen in gerelateerde dilemma's of problemen. Zij bieden aldus een niet-ideale toegepaste theorie van de rechtvaardige oorlog. Hierbij gaan ze niet uit van onvoorwaardelijke normatieve principes behorend tot een eenduidige algemene ethische theorie. Daarnaast spelen verschillende morele en prudentiële overwegingen een belangrijke rol. Soms moeten compromissen gesloten worden teneinde een effectieve theorie te creëren. Geen enkele handelswijze is rechtvaardig in een algemene of absolute zin. Een bepaalde handeling is wellicht de meest rechtvaardige (of de minst onrechtvaardig) gezien de omstandigheden en de alternatieven die voorhanden zijn. De theorie is, in zekere zin, bescheiden van aard. Conventionalisten bekommeren zich minder om de theoretische doelstelling en laten als gevolg daarvan relevante abstracte normatieve principes onderbelicht. Walzer geeft bijvoorbeeld aan dat hij zich niet direct bezighoudt met de fundamentele vragen van de moraalfilosofie. Wij leven in de 'bovenbouw' van de ethiek, en het is niet per se nodig om eerst de 'onderbouw' totaal te doorgronden. Bovendien is 'de onderbouw van de ethiek (...) een kwestie waarover men diep en kennelijk eindeloos van oordeel kan verschillen'. Daarom moeten we de praktische moraal maar even los van haar oorsprong beschouwen, zo stelt Walzer heel pragmatisch $(2018,26)$.

De revisionisten richten zich daarentegen juist zeer sterk op de theoretische doelstelling. Het doel is een weerspiegeling te geven van de juiste normen, afgeleid uit abstracte morele principes. Er worden geen compromissen gesloten en daarmee lijkt de theorie coherenter te zijn. Zij argumenteren op basis van een ideale wereld en bieden een abstractere theorie, waarbij omstandigheden geïdealiseerd worden en bepaalde eigenschappen van het fenomeen oorlog niet worden meegenomen in de theorievorming. Dit is een bewuste keuze. Door deze abstractie en het gebruik van hypothetische voorbeelden (los van de praktijk) wordt een groter inzicht verkregen. De complexe werkelijkheid kan dingen verhullen, zo wordt verondersteld, en normen kunnen gemakkelijker geïdentificeerd worden zonder de mist die rondom historische gebeurtenissen hangt (Frowe 2016: 1). De praktische doelstelling komt daardoor echter nauwelijks in het blikveld. Revisionisten tonen over het algemeen weinig belangstelling voor de oorlogsomstandigheden waarin de morele beslissingen genomen worden. En dit wordt ook niet onder stoelen of banken gestoken. Zo beschrijft Fabre het 
voornaamste doel van haar boek Cosmopolitan War (2012) bijvoorbeeld als volgt: 'to unearth first best principles' (Fabre 2012: 12). McMahan stelt ook duidelijk dat hij gericht is op het verklaren van de 'diepe moraliteit' van oorlog, en niet op het ontwikkelen van praktische richtlijnen (bv. McMahan 2004). Wat zij formuleren lijkt een algemene ethische theorie te zijn, maar dan toegepast op oorlog.

Het is duidelijk dat beide posities een andere focus hebben en als gevolg daarvan op verschillende gebieden uitspraken doen. Conventionalisten en revisionisten bieden, met andere woorden, een ander type normatieve theorie: een toegepaste ethische theorie versus een algemene ethische theorie. Niettemin zouden beide posities hun theorie kunnen verbeteren. Ik wil suggereren dat, door te kijken naar de sterke punten van de ander, zowel conventionalisten als revisionisten hun theorie completer en overtuigender kunnen maken. In de vierde sectie gaf ik aan dat een toegepaste ethische theorie, zoals de theorie van de rechtvaardige oorlog, de theoretische en praktische doelstelingen zou moeten combineren. Een complete en overtuigende theorie van de rechtvaardige oorlog doet uitspraken op beide gebieden. Het is daarom voor de conventionalisten belangrijk om aan te geven op welke abstracte normatieve principes hun theorie gebaseerd is. Wat is de rechtvaardiging voor de normen die voorgesteld worden? Wanneer de 'onderbouw' van de ethiek wel wordt doorgrond zou dat de conventionele theorie enorm versterken. Hoe kunnen we bijvoorbeeld precies verklaren dat een schending van soevereiniteit zo problematisch is dat dit een verdediging van de politieke gemeenschap rechtvaardigt, zelfs al worden er geen individuele rechten geschonden? Hoe kunnen we binnen een kader van individuele rechten verklaren dat combattanten, schuldig of onschuldig, elkaars legitieme doelen zijn? En welke abstracte normatieve principes geven richting aan de naoorlogse vredesopbouw? Er zijn theoretici die proberen de conventionele substantiële normen (e.g. de morele gelijkheid van combattanten) sterker te funderen en verklaren door zich te richten op deze onderbouw van de ethiek (Lazar 2015, Shue 2010, Benbaji 2011, Steinhoff 2008). Conventionalisten zouden deze bijdragen moeten verwelkomen. Zij kunnen hun theorie verbeteren door de gedragscode te verbinden met abstracte normatieve principes. Dit komt de coherentie ten goede, geeft de praktische richtlijnen meer kracht en legitimiteit, ondervangt de voorwaardelijkheid en afhankelijkheid van conventies en contemporaine oorlogssituaties, en eventuele kritiek dat de normen ongefundeerd zijn en daarmee berusten op drijfzand. ${ }^{39}$

\footnotetext{
${ }^{39}$ Wellicht kan de conventionele theorie aan duidelijkheid winnen door de casuïstische methode aan te vullen met een analyse van hypothetische voorbeelden waarbij de vorming van morele oordelen niet beïnvloed wordt door impliciete persoonlijke opvattingen en onenigheid over historische gebeurtenissen. Abstraheren van de
} 
Ook de revisionistische theorie zou verbeterd kunnen worden. In sectie 4 stelde ik dat de praktische doelstelling centraal staat bij een toegepaste ethische theorie. Dit type theorie moet een gedragscode bieden die daadwerkelijk richting geeft aan gedrag. Wat - gezien deze speciale rol van de theorie van de rechtvaardige oorlog - onvoldoende erkend wordt door revisionisten is dat oorlog een zeer specifiek domein is dat niet enkel verklaard kan worden door abstracte normatieve principes simpelweg toe te passen op een bepaalde context. Vanwege het niet meenemen van de extreme omstandigheden van oorlog, de kloof tussen het collectieve karakter van oorlog en het individualistische model, en het uitsluiten van allerlei empirische en epistemologische beperkingen, hebben gereviseerde substantiële normen minder praktische waarde dan de conventionele normen. ${ }^{40}$ Ze slagen er niet optimaal in richting te geven aan gedrag in de oorlogssituatie waarin morele schuld vaak onduidelijk is, of in de nasleep van oorlog waarbij er vaak zoveel schade is toegebracht dat al te idealistische doelstellingen onhaalbaar zijn. Het is te eenvoudig om te stellen dat men zich slechts richt op de 'diepe moraliteit van oorlog' of de first best principles, en dat deze normen in de praktijk inderdaad dan wel moeilijk toepasbaar zijn, maar dat dit de geldigheid van de normen niet ondermijnt (e.g. McMahan). De specifieke context is essentieel bij het formuleren van een toegepaste ethiek op een bepaald terrein, en moet in aanmerking genomen worden. Er is, met andere woorden, een vertaalslag nodig die het fenomeen van oorlog in aanmerking neemt (net zoals andere toegepaste ethische theorieën ten aanzien van bijvoorbeeld medische vraagstukken of dierenrechten). ${ }^{41}$ Daarom is de revisionistische theorie onvolledig. De theorie van de rechtvaardige oorlog zou een toegepaste ethische theorie moeten zijn die niet alleen coherent is en gebaseerd op heldere morele principes, maar ook richtlijnen biedt voor de onstuimige werkelijkheid waarop ze van toepassing is. De uitdaging voor revisionisten is het behouden van de theoretische coherentie wanneer zij met de praktische doelstelling voor ogen hun theorie completeren.

Daarnaast moeten de risico's van een revisionistische rechtvaardige oorlogstheorie in aanmerking worden genomen. Doordat deze vertaalslag vaak niet ondernomen wordt, en daarmee een algemene ethische theorie wordt gepresenteerd als een toegepaste ethiek, liggen er specifiek twee gevaren op de loer: 1) het gevaar van misleiding en 2) het gevaar van contraproductiviteit. Ik heb in de vorige sectie aangegeven dat de revisionistische normen niet

complexe werkelijkheid kan waardevol zijn doordat het aspecten of omstandigheden isoleert, en daarmee beter inzicht geeft in relevante morele overwegingen (vgl. David 2012: 9).

${ }^{40}$ Rigstad overweegt ten aanzien van McMahan's theorie dat: 'One therefore has to wonder about the purpose of writings books on how to kill reflectively, and upon due deliberation, for a society that trains its soldiers to kill automatically, without a moment's hesitation.' Rigstad (2017: 134).

${ }^{41}$ Zie ook Lazar (2012: 370). 
altijd goed toepasbaar zijn; zij maken vaak een conceptuele 'in principe' claim, gebaseerd op geïdealiseerde en ver van de praktijk afstaande hypothetische voorbeelden. ${ }^{42}$ Mijn zorg hierbij is dat dergelijke claims niet alleen minder relevant zijn, maar dat deze abstractie en idealisering ook misleidend kunnen zijn. Dit gebeurt bijvoorbeeld op het niveau van kennis (soldaten hebben net als de bewaker in de bank onvoldoende kennis om de mate van schuld van de tegenstander te bepalen), het niveau van de specifieke omstandigheden (er is een terrorist in hechtenis die informatie zal loslaten over de geplaatste bom wanneer hij wordt gemarteld) of op het niveau van de condities waaronder bepaalde normen van toepassing zijn (als Pogge's theorie ten aanzien van de oorzaken van internationale armoede klopt, dan hebben de armen een rechtvaardige reden voor oorlog tegen de rijken) (McMahan 2004, Shue 2006, Lippert-Rasmussen 2013, 2017). Wat als dergelijke idealiseringen of 'als' condities nooit opgaan in de werkelijkheid? Wanneer dit soort kennis, omstandigheden of condities in de praktijk eigenlijk nooit aanwezig zijn, dan ondermijnt dit niet alleen de claim maar maakt het de claim in zekere zin ook misleidend. Op basis van een dergelijke 'in principe' claim wordt de suggestie gewekt dat een praktische richtlijn geboden wordt, terwijl deze richtlijn in werkelijkheid niet praktisch leidend is omdat de omstandigheden in de echte wereld heel anders zijn.

Bovendien wijzen verschillende theoretici erop dat revisionistische normen een nog groter gevaar met zich meebrengen. Aandringen op herzieningen vanuit een abstracte ideale theorie kan er namelijk voor zorgen dat de consensus op het gebied van de 'oorlogsconventie' ondermijnt wordt. Zoals eerder genoemd heeft deze conventie tot doel menselijk lijden zoveel mogelijk te beperken. De revisionistische normen dragen het risico in zich contraproductief te zijn wanneer ze worden toegepast op de praktijk van oorlog. De afwijzing van noncombattanten immuniteit communiceren aan niet-alwetende combattanten kan leiden tot een toename van het aantal burgerslachtoffers; het bepleiten van gerechtvaardigde marteling in hypothetische ticking bomb scenario's kan leiden tot een toename van gemartelde terrorismeverdachten, en het erkennen van armoede als rechtvaardige reden voor oorlog kan leiden tot in toename van geweld gepleegd door armen in een poging hun rechten te claimen (Shue 2006, Statman 2014: 351, Rigstad 2017: 142). McMahan bijvoorbeeld, vraagt zich terecht af of het wellicht zo is dat 'the stakes are too high to allow for much experimentation with alternatives' (McMahan 2004: 731). In een recent hoofdstuk belicht Jeremy Waldron

\footnotetext{
${ }^{42}$ Fabre bijvoorbeeld, geeft in de conclusie van haar hoofdstuk over subsistence wars toe dat er mensen zullen zijn die tegen haar claim inbrengen dat 'those wars are so seldom just, that the issue is not worth addressing' (2012: 128).
} 
(2018: hfdst. 4) de fragiele aard van de oorlogsconventie, bijvoorbeeld non-combattanten immuniteit. Vanwege het gebrek aan gezaghebbende handhavingsorganen en de unsupervised self-application van deze normen is het risico op ondermijning en niet nakoming groot. Dit maakt dat er extra voorzichtigheid geboden is als het gaat om het leveren van kritiek op de conventionele normen.

\section{Conclusie}

In dit artikel heb ik een schets gegeven van de diepe verdeeldheid en spanningen binnen de theorie van de rechtvaardige oorlog. De substantiële verschillen tussen de twee posities in het debat - conventionalisme en revisionisme - zijn terug te voeren op fundamenteel verschillende theoretische uitgangspunten. Inzicht in deze uitgangspunten maakt het mogelijk het huidige debat, en individuele bijdragen daaraan, beter te begrijpen. Wat vooral opvalt is dat er tussen beide posities een bepaalde taakverdeling bestaat: beide posities hebben een verschillende focus en bieden een ander type normatieve theorie. Dit inzicht kan bijdragen aan een wapenstilstand.

Wanneer we kijken naar het domein van oorlog (en veel andere domeinen) dan kunnen we (zie sectie vier) minimaal drie verschillende normenstelsels identificeren: 1) algemene ethische theorie/abstracte normatieve principes, 2) toegepaste ethische theorie, en 3) het recht. In beginsel kunnen deze normenstelsels coherent naast elkaar bestaan. Een driedelig overzicht geeft echter de meest volledige weergave van het relevante normatieve kader. Dit is helaas zeldzaam in de literatuur. Zoals we hebben gezien erkent Walzer (1) maar laat dit onderbelicht terwijl hij zich richt zich op (2) als een morele fundering van (3). McMahan identificieert slechts twee normenstelsels, (1) en (3), en richt zich vooral op (1). Hij erkent echter dat het moeilijk is om 1) toe te passen op de realiteit van oorlog, en geeft toe dat (3) daarom een nuttige conventie is waar combattanten zich in niet ideale omstandigheden aan moeten houden (McMahan 2010, zie ook Fabre 2010, Frowe 2011). Als we, zo stelt McMahan, maar onthouden dat ze zich daarmee dan wel juridisch juist, maar niet moreel juist gedragen. Andere revisionisten, zoals Fabre en Evans, erkennen steeds vaker (1), (2), en (3), waarbij ze zich richten op (1), maar de moeilijke toepasbaarheid op het fenomeen oorlog erkennende geven zij uiteindelijk ook een toegepaste niet-ideale theorie: de second best principles, of suboptimal norms (Fabre 2016, Evans 2014).

Mijn suggesties voor versterking en verrijking van beide posities zijn ingegeven door de aanname dat dit gehele normatieve kader relevant is wanneer we kijken naar het fenomeen 
oorlog. En hoewel juridische normen wellicht het beste door juristen bestudeerd kunnen worden $^{43}$, zijn de twee eerste normenstelsels essentieel voor filosofen die een reflectie willen bieden op de ethiek van oorlog. Ondanks dat rechtvaardige oorlogstheoretici duidelijk kunnen aangeven wat hun aspiraties zijn, i.e. welk doel zij wel en welk doel zij niet nastreven, is het wenselijk dat zij uitspraken doen op beide gebieden. De theorie is niet compleet wanneer er slechts een weergave wordt gegeven van een enkel normenstelsel. Een volledige en overtuigende theorie van de rechtvaardige oorlog beantwoord aan alle vier criteria, en verbindt abstracte normatieve principes en praktisch toepasbare normen. Dat betekent dat conventionalisten meer aandacht zouden moeten besteden aan (1). Een toegepaste ethische theorie is het sterkste wanneer die stevig gefundeerd is en duidelijk maakt op welke abstracte normatieve principes de normen gebaseerd zijn. Zij kunnen aldus hun theorie versterken door een stevigere basis te zoeken voor de morele normen die ze voorstellen. Revisionisten zouden meer aandacht moeten besteden aan (2). De recente ontwikkeling waarbij revisionisten zoals Fabre en Evans hun abstracte theorie aanvullen met praktisch toepasbare normen, is zeer positief. Wanneer zij dat doen bieden zij een volledige, relevante en bovendien toepasbare theorie, en ondervangen zij het risico op misleidende en contraproductieve normen.

Kan er ook iets gezegd worden over het wel of niet voortduren van de 'oorlog' tussen beide posities? In de inleiding opperde ik de mogelijkheid van een verzoening of wapenstilstand. Gezien de heftigheid van de discussies en de belichte theoretische verschillen, is een verzoening waarschijnlijk een brug te ver. Maar zoals ik heb proberen te laten zien vullen beide theorieën elkaar op een bepaalde manier ook goed aan, en bieden zij beiden een zeer waardevolle bijdrage aan het ethische debat over oorlog. Inzicht in de onderliggende verschillen en een erkenning van een bepaalde focus en taakverdeling, kunnen ontvankelijkheid voor andere inzichten stimuleren. Bovendien is te hopen dat zij zich meer voor elkaar gaan opstellen, waarbij voorstanders van beide zijden inderdaad van elkaar kunnen leren om daarmee een completere theorie te kunnen creëren.

\footnotetext{
${ }^{43}$ Maar zie in dit verband het uitstekende werk van Adil Haque, Law and Morality at War (2017).
} 


\section{Bibliografie}

Benbaji, Y. (2008) A Defense of the Traditional War Convention, Ethics 118 (3), pp. 464-95.

Benbaji Y. (2011) The Moral Power of Soldiers to Undertake the Duty of Obedience, Ethics 122 (1), pp. 43-73.

Black, J. (2007) What is War?: Some Reflections on a Contested Concept, RUSI, 152 (6), pp. 42-45.

Brown, C. (2017) The Historical Approach and the 'War of Ethics within the Ethics of War', Journal of International Political Theory 14 (3), pp. 1-18.

Brownlee, K. en Stemplovska, S. (2017), Trapped in an Experience Machine with a Famous Violinist, in: A. Blau (red.), Research Methods in Analytical Political Theory. Cambridge: Cambridge University Press, pp. 21-45.

Ceulemans, C. (2010) Over Oorlog en Ethiek. Antwerpen: Garant Uitgevers.

Coates, A. (2016) The Ethics of War. Manchester: Manchester University Press.

Creveld, M. van (1991) The Transformation of War. New York: The Free Press.

Dennett, D. (2013) Intuition Pumps and Other Tools for Thinking. New York: W.W. Norton.

Dill, J. (2018) Just War Theory in Times of Individual Rights, in: C. Brown en R. Eckersley (red.), The Oxford Handbook of International Political Theory. Oxford: Oxford University Press, pp. 221232.

Draper, K. (2016) War and Individual Rights. Oxford: Oxford University Press.

Elster, J. (2011) How Outlandish Can Imaginary Cases Be?, Journal of Applied Philosophy 28 (3), pp. 241-258.

Evans, M. (2005) Just War Theory: A Reappraisal. Edinburgh: Edinburgh University Press.

Evans, M. (2009) Moral Responsibilities and the Conflicting Demands of Jus Post Bellum, Ethics \& International Affairs 23 (2), pp. 147-164.

Evans, M. (2014), At War's End. Time to Turn to Jus Post Bellum?, in: C. Stahn en J. S. Easterday (red.), Jus Post Bellum: Mapping the Normative Foundations. Oxford: Oxford University Press, pp. 26-42.

Fabre, C. (2012) Cosmopolitan War. Oxford: Oxford University Press.

Fabre, C. (2016) Cosmopolitan Peace. Oxford: Oxford University Press.

Fotion, N. (2014) Theory vs Anti-Theory a Misconceived Conflict. Oxford: Oxford University Press.

Frowe, H. (2014) Defensive Killing. Oxford: Oxford University Press.

Frowe, H. (2016) The Ethics of War and Peace: An Introduction. London: Routledge.

Harris, C. (1997) Applying Moral Theories. 3e editie. Belmont: Wadsworth.

Harsanyi, J. (1982), Some Epistemological Advantages of a Rule Utilitarian Position in Ethics, Midwest Studies in Philosophy 8, pp. 389-402.

Haque, A. (2017), Law and Morality at War. Oxford: Oxford University Press.

Hurka, T. (2005), Proportionality in the Morality of War, Philosophy \& Public Affairs 33 (1), pp. 3466. 
Lazar, S. (2012), The Morality and Law of War, in: A. Marmor (red.), Routledge Companion to Philosophy of Law. London: Routledge.

Lazar, S. (2017a), Evaluating the Revisionist Critique of Just War Theory, Daedalus 146 (1), pp. 113124.

Lazar, S. (2017b) Just War Theory: Revisionists vs. Traditionalists, Annual Review of Political Science 20, pp. 37-54.

Lazar, S. (2018) Method in the Morality of War, in: S. Lazar en H. Frowe (red.), Oxford Handbook of the Ethics of War. Oxford: Oxford University Press, pp. 21-40.

Lippert-Rasmussen, K. (2013), Global Injustice and Redistributive Wars, LEAP 1, pp. 65-84.

Lippert-Rasmussen, K. (2017), Pogge, Poverty and War, Politics, Philosophy \& Economics 16 (4), pp. $1-24$.

List, C. en Valentini, L. (2016) The Methodology of Political Theory, in: H. Cappelen en T. Szabo Gendler (red.), The Oxford Handbook of Philosophical Methodology. Oxford: Oxford University Press.

McMahan, J. (1994), Innocence, Self-Defense and Killing in War, The Journal of Political Philosophy 2 (3), pp. 193-2210

McMahan, J. (2004), The Ethics of Killing in War, Ethics 114 (4), pp. 693-733.

McMahan, J. (2009) Killing in War. Oxford: Oxford University Press.

McMahan, J. (2010) The Laws of War, in: The Philosophy of International Law. New York: Oxford University Press, pp. 493-510.

McMahan, J. (2012), Rethinking the 'Just War', New York Times, https://opinionator.blogs.nytimes.com/2012/11/11/rethinking-the-just-war-part-1/ en https://opinionator.blogs.nytimes.com/2012/11/12/rethinking-the-just-war-part-2/

Orend, B. (2013) The Morality of War. Peterborough: Broadview Press.

Pattison, J. (2018a) The Case for the Nonideal Morality of War: Beyond Revisionism versus Traditionalism in Just War Theory, Political Theory 43 (2), pp. 242-268.

Pattison, J. (2018b) Alternatives to War: From Sanctions to Nonviolence. Oxford: Oxford University Press.

Peperkamp, L., en Tinnevelt, R. (2017) Rechtvaardige Oorlog en Mondiale Rechtvaardigheid: Het Probleem van Hulpbronnenoorlogen, Tijdschrift voor Filosofie 79 (4), pp. 643-681.

Pogge, T. (2013), Poverty and Violence, Law, Ethics and Philosophy 1 (1), pp. 87-111.

Pullock, L. (1988), Evaluating Moral Theories, American Philosophical Quarterly 25 (3), pp. 229240.

Rawls, J. (1999), The Law of Peoples. Cambridge: Harvard University Press.

Reichberg (2018), Historiography of Just War Theory, in: S. Lazar en H. Frowe (red.), Oxford Handbook of the Ethics of War. Oxford: Oxford University Press, pp. 59-79. 
Rigstad, M. (2017), Putting the War Back in Just War Theory, Ethical Perspectives 24 (1), pp. 123144.

Rodin, D. (2003) War \& Self-Defense. Oxford: Oxford University Press.

Rodin, D. (2008), The Moral Inequality of Soldiers: Why Jus in Bello Asymmetry Is Half Right, in: D. Rodin (red.), Just and Unjust Warriors: The Moral and Legal Status of Soldiers. Oxford: Oxford University Press.

Rodin, D. (2011), Morality and Law in War, in: H. Strachan en S. Scheipers (red.), The Changing Character of War. Oxford: Oxford University Press, pp. 446-463.

Shue, H. (2006), Torture in Dreamland: Disposing of the Ticking Bomb, Case Western Reserve Journal of International Law 37, pp. 231-239.

Shue, H. (2010), Laws of War, in: S. Besson en J. Tasioulas (red.), The Philosophy of International Law. New York: Oxford University Press, pp. 511- 530.

Statman (2014), Fabre's Crusade for Justice: Why We Should Not Join, Law and Philosophy 33, pp. $337-360$.

Steinhoff, U. (2007) On the Ethics of War and Terrorism. Oxford: Oxford University Press.

Steinhoff, U. (2012), Rights, Liability, and the Moral Equality of Combatants, Journal of Ethics 16 (4), pp. 339-366.

Timmons (2013) Conduct \& Character: Readings in Moral Theory. Belmont, CA: Wadsworth Publishing Co Inc.

Vaha, M. (2013), The Ethics of War, Innocence, and Hard Cases: A Call for a Middle Ground, in: C. Navari (red.), Ethical Reasoning in International Affairs: Arguments from the Middle Ground. Basingstoke: Palgrave Macmillan, pp. 182-202.

Waldron, M. (2018), Deep Morality and the Laws of War, in: S. Lazar en H. Frowe (red.), The Oxford Handbook of Ethics of War. Oxford: Oxford University Press, pp. 80-97.

Walzer, M. (2006a), Rechtvaardige en Onrechtvaardige Oorlogen: Een Ethische Beschouwing met Historische Illustraties. Amsterdam: Uitgeverij Atlas.

Walzer, M. (2006b), Response to McMahan's Paper, Philosophia 34 (1), pp. 43-45.

Walzer, M. (2015[1977]), Just and Unjust Wars: A Moral Argument with Historical Illustrations, 5e editie. New York: Basic Books.

\section{Over de auteur}

Lonneke Peperkamp is universitair docent Rechtsfilosofie aan de Radboud Universiteit Nijmegen. In 2017 promoveerde zij op het proefschrift Jus Post Bellum and the Nature of Peace aan diezelfde universiteit (gefinancierd door een NWO 'Toptalent' subsidie). Ze werkte daarna als visiting assistant professor Politics and Public Administration aan The 
University of Hong Kong. Haar voornaamste onderzoeksinteresses liggen op het gebied van de theorie van de rechtvaardige oorlog, vrede en vredesopbouw, filosofie van mensenrechten, armoede en mondiale distributieve rechtvaardigheid. 